\title{
Comparison of Ferric Carboxymaltose and Oral Iron Treatments in Iron Deficiency Anemia
}

\author{
Demir Eksikliği Anemisinde Ferrik Karboksimaltoz ile Oral Demir Tedavisinin Karșılaștırılması
}

\author{
Muharrem Bayrak, Kenan Çadırcı \\ Department of Internal Medicine, Health Sciences University, Erzurum Regional Training and Research Hospital, Erzurum, Turkey
}

\begin{abstract}
Aim: Iron deficiency anemia (IDA) is one of the most important health problems in both fertile women and children living in developing countries. This condition must be treated quickly and safely. The present study aimed to compare the efficacies of intravenous ferrous carboxymaltose treatment and oral iron treatment in reproductive-aged women with IDA.
\end{abstract}

Material and Method: This retrospective study included 202 reproductive-aged women who were diagnosed as IDA with a hemoglobin level of $<11 \mathrm{~g} / \mathrm{dL}$. Patients were divided into two groups to be administered a single dose of $1000 \mathrm{mg}$ intravenous ferric carboxymaltose $(n=112)$ and $325 \mathrm{mg} /$ day oral ferrous sulphate $(n=90)$ for four weeks. All the anemia parameters of the patients were compared before and after treatment.

Results: There were significant increases in hemoglobin concentration, ferritin values, and transferrin saturation levels after treatment in both groups. However, the increases in these values were significantly higher in the group receiving ferric carboxymaltose $(p<0.001)$. There was no significant difference in the side effects between the group receiving ferric carboxymaltose and the group receiving oral ferrous sulphate (6.7\% vs. $8.9 \%$, $p=0.554$ ).

Conclusion: Ferric carboxymaltose treatment could be used effectively and reliably in patients who could not tolerate oral iron treatment.

Key words: iron deficiency anemia; ferrous sulphate; ferric carboxymaltose; side effects; efficacy

\section{ÖZET}

Amaç: Demir eksikliği anemisi (DEA), hem doğurgan kadınlarda ve hem de gelișmekte olan ülkelerde yașayan çocuklarda en önemli sağlık sorunlarından biridir. Bu durumun hızlı ve güvenli bir șekilde tedavi edilmesi önemlidir. Bu çalıșma, demir eksikliği anemisi olan üreme çağındaki kadınlarda intravenöz ferrik karboksimaltoz tedavisi ve oral demir tedavisinin etkilerini karșılaștırmayı amaçlamıștır.
Materyal ve Metot: Bu retrospektif çalıșmaya, DEA tanısı olan ve hemoglobin düzeyi $<11 \mathrm{~g} / \mathrm{dL}$ olan 202 reprodüktif dönemde kadın hasta alındı. Hastalar, dört hafta boyunca tek bir doz 1000 mg intravenöz ferrik karboksimaltoz ( $n=112$ ) ve $325 \mathrm{mg} / g u ̈ n$ oral demir sülfat (n=90) uygulanacak șekilde iki gruba ayrıldı. Hastaların tüm anemi parametreleri tedavi öncesi ve sonrası karșilaștıııldı.

Bulgular: Her iki grupta tedaviden sonra hemoglobin konsantrasyonunda, ferritin değerlerinde ve transferrin doygunluk seviyelerinde önemli artıșlar vardı. Bununla birlikte, bu değerlerdeki artıșlar ferrik karboksimaltoz alan grupta anlamlı olarak daha yüksekti $(p<0,001)$. Ferrik karboksimaltoz alan grup ile oral demir sülfat alan grup arasında yan etkiler açısından anlamlı fark yoktu (\%6,7'ye karșı \%8,9, $p=0,554$ ).

Sonuç: Ferrik karboksimaltoz tedavisi, oral demir tedavisini tolere edemeyen hastalarda etkili ve güvenilir bir șekilde kullanılabilir.

Anahtar kelimeler: demir eksikliği anemisi; ferröz sülfat; ferrik karboksimaltoz; yan etki; etkinlik

\section{Introduction}

Iron deficiency anemia (IDA) is a health problem encountered in preschool children, pregnant women, women of reproductive age, and nearly $25 \%$ of individuals of advanced age worldwide ${ }^{1}$. IDA can be seen in some pathological conditions such as chronic diseases, bleeding, malnutrition, and chronic inflammation. It is associated with numerous symptoms like fatigue, low performance, and weakness ${ }^{2}$. According to the World Health Organization, a hemoglobin level of $12 \mathrm{~g} / \mathrm{dL}$ in non-pregnant women is defined as IDA ${ }^{3}$. Reduction in hemoglobin concentration by more than $2 \%$ is associated with morbidity and mortality ferrous sulphate ${ }^{4}$.

IIetișim/Contact: Muharrem Bayrak, Health Sciences University, Erzurum Regional Training and Research Hospital, Department of Internal Medicine, 25240 Erzurum, Turkey • Tel:05385555933 • E-mail: mubabayrak@hotmail.com • Geliș/Received: 14.11.2019 • Kabul/Accepted: 18.02 .2020

ORCID: Muharrem Bayrak, 0000-0003-2760-4181 • Kenan Çadirc1, 0000-0002-2765-4288 
Iron deficiency anemia should be treated regardless of whether it is symptomatic or not ${ }^{5}$. Today, oral or intravenous iron preparations are used for the treatment of IDA. The oral iron treatment has some disadvantages, such as gastrointestinal side effects, long-term treatment period, and high total cost. Gastrointestinal side effects have been reported to be encountered in $70 \%$ of IDA patients treated with oral iron preparations (especially ferrous sulphate) ${ }^{6}$. Although intravenous iron preparations have limited usage because of serious adverse events, they are increasingly being used in clinically necessary situations. Currently used intravenous iron preparations include iron dextran, ferric gluconate, and iron sucrose. Ferric carboxymaltose has been recently licensed by various drug licensing committees and is used in patients intolerant to oral iron treatment or in need of a rapid increase in hemoglobin concentration ${ }^{7}$. Although the effects of ferric carboxymaltose have been investigated in various patient groups, studies on its efficacy remain lacking. The present study aimed to compare the efficacies of intravenous ferric carboxymaltose and oral ferrous sulphate in reproductive-aged women diagnosed with IDA.

\section{Materials and Methods}

This was a retrospective registry study of 18-44-year old women diagnosed with IDA between January 1, 2015, and May 30, 2018. Women who had a hemoglobin concentration of $<11 \mathrm{~g} / \mathrm{dL}$ were included; however, those having any other systemic disease or other hematological pathologies and those being pregnant were excluded.

Patients were dichotomized according to the treatment they received: ferric carboxymaltose (Vifor Pharma Management Ltd. Glattbrugg, Switzerland) or oral ferrous sulphate. Patients in whom hemoglobin concentration was intended to be elevated rapidly received ferric carboxymaltose at a single dose of 1000 $\mathrm{mg} /$ day via intravenous infusion for 15 minutes. The remaining patients received ferrous sulphate at a dose of $325 \mathrm{mg}$ once daily for four weeks. Either the patients in the intravenous ferric carboxymaltose group or the patients in the oral ferrous sulphate group had never received intravenous iron treatment before. All of the patients in the ferric carboxymaltose group had used oral iron preparations for at least one year and were developed gastrointestinal side effects such as nausea, vomiting, and diarrhea. In the ferrous sulphate group, eight patients had received oral iron therapy before.
None of the patients in both groups had a history of documented allergy.

Data of the patients on age, hemoglobin concentration, ferritin value, and transferrin saturation were recorded before the treatment. Hemoglobin concentration, ferritin value, and transferrin saturation were measured one month again after the treatment. Transferrin saturation (\%) was calculated using the following formula: serum iron/total iron-binding capacity $\times 100$. Posttreatment complications were questioned in detail and then recorded.

The study protocol was approved by the local Ethics Committee (No: 2018/16-151). The written general informed consent of the patients was obtained.

\section{Statistical Analysis}

Data were analyzed using the IBM SPSS Statistics for Windows, Version 20.0 (IBM Corp., Armonk, NY, USA). Continuous variables were expressed as the median, interquartile range (25th percentile [Q1]-75th percentile [Q3]), and categorical variables were expressed as frequency and percentage. The Shapiro Wilk test was used to determine the distribution normality of data. Comparison of categorical variables was performed using the Pearson chi-square test. In a comparison of continuous variables obtained before and after treatment, paired-samples t-test was used for normally distributed numerical variables, and the Wilcoxon signed-rank test was used for non-normally distributed numerical variables. The level of significance was predetermined to be $\mathrm{p}<0.05$.

\section{Results}

The present study included 202 patients, of whom 112 were in the intravenous ferric carboxymaltose group, and 90 were in the oral ferrous sulphate group. The median age of the patients was 29 years (24-37.5 years) in the intravenous ferric carboxymaltose group and 29.5 years (22-40 years) in the oral ferrous sulphate group. There was no significant difference between the treatment groups in terms of age $(p=0.558)$.

Regarding the distribution of pre-treatment and post-treatment median hemoglobin concentration, ferritin value, and transferrin saturation in the treatment groups, all parameters significantly elevated in both study groups after the treatment $(p<0.001$ for both). Distribution of pretreatment and post-treatment biochemical parameters in the study groups are 
Table 1. Distribution of pre-treatment and post-treatment biochemical parameters in the treatment groups

\begin{tabular}{|c|c|c|c|c|c|c|c|c|}
\hline & \multicolumn{8}{|c|}{ Treatment groups } \\
\hline & \multicolumn{4}{|c|}{ Oral ferrous sulphate } & \multicolumn{4}{|c|}{ Intravenous ferric carboxymaltose } \\
\hline & $\begin{array}{c}\text { Pre-treatment } \\
\text { Median (Q1-Q3) }\end{array}$ & $\begin{array}{l}\text { Post-treatment } \\
\text { Median (Q1-Q3) }\end{array}$ & $\begin{array}{c}\text { Difference } \\
\text { Median (Q1-Q3) }\end{array}$ & $\mathrm{p}^{\star}$ & $\begin{array}{c}\text { Pre-treatment } \\
\text { Median (Q1-Q3) }\end{array}$ & $\begin{array}{l}\text { Post-treatment } \\
\text { Median (Q1-Q3) }\end{array}$ & $\begin{array}{c}\text { Difference } \\
\text { Median (Q1-Q3) }\end{array}$ & $\mathrm{p}^{*}$ \\
\hline Hemoglobin & $10.4(10.2-10.7)$ & $11.1(10.7-11.4)$ & $0.5(0.4-0.9)$ & $<0.001$ & $9.8(9.3-10.3)$ & $11.5(10.8-11.8)$ & $1.5(0.8-2.2)$ & $<0.001$ \\
\hline Ferritin & $4.1(2.7-5.8)$ & $28(21-33)$ & $22.4(16.3-28.5)$ & $<0.001$ & $5.3(3.6-7)$ & $82(55.5-95.5)$ & $77.0(49.2-90.1)$ & $<0.001$ \\
\hline Transferrin saturation & $8.1(6.9-9.2)$ & $20.7(19.5-22.1)$ & $12.7(10.9-14.2)$ & $<0.001$ & $3.3(2.3-4.15)$ & $38.9(35.05-42.6)$ & $35.6(32.4-39.6)$ & $<0.001$ \\
\hline
\end{tabular}

presented in Table 1. Ferric carboxymaltose treatment was associated with a higher increase in hemoglobin concentration, ferritin value, and transferrin saturation as compared with oral ferrous sulphate treatment $(\mathrm{p}<0.001$ for each). The distribution of hemoglobin concentration in the treatment groups is demonstrated in Figure 1.

Side effect (mild urticaria) was seen in $6(6.7 \%)$ of the patients receiving oral ferrous sulphate $(\mathrm{n}=90)$ and in $10(8.9 \%)$ of the patients receiving intravenous ferric carboxymaltose treatment. There was no significant difference between the treatment groups in terms of the presence of side effects $(\mathrm{p}=0.554)$.

\section{Discussion}

Today, oral iron preparations are the first choice-oftreatment of IDA. However, gastrointestinal side effects, the need for long-term treatment as well as the requirement of long-term activity are the limitations of oral iron treatment. In the present study, we evaluated the efficacy and side effect profile of intravenous ferric carboxymaltose by comparing with oral ferrous sulphate in the reproductive-aged women with IDA, who were intolerant to oral iron treatment and in whom hemoglobin concentrations were needed to be elevated rapidly. This comparison revealed that the elevations in hemoglobin concentration, ferritin value, and transferrin saturation were significantly higher in the women receiving ferric carboxymaltose than in those receiving oral ferrous sulphate $(\mathrm{p}<0.001)$.

A single administration of intravenous ferric carboxymaltose at high doses is one of its superiority to oral iron treatment. Therefore, clinical studies have mostly focused on IDA during pregnancy. In the literature, studies conducted in pregnant women have presented evidence that ferric carboxymaltose is an effective option in pregnancy ${ }^{8-10}$. The present study also demonstrated that ferric carboxymaltose treatment is associated with a higher increase in hemoglobin concentration, ferritin value, and transferrin saturation as compared with t oral ferrous sulphate treatment. Similarly, a study of 264 geriatric patients revealed significant increases in hemoglobin concentration, ferritin value, and transferrin saturation after ferric carboxymaltose treatment ${ }^{11}$. In addition, a meta-analysis of 10.605 patients reported that intravenous iron treatment increased hemoglobin level by $6.5 \mathrm{~g} / \mathrm{L}$ and was associated with lower blood transfusion ${ }^{12}$. Some studies conducted in Turkey also demonstrated favorable effects of intravenous iron preparations on clinical parameters ${ }^{13-14}$. Evaluating the literature together with the results of the present study, intravenous iron treatment can be safely used in IDA patients.

Numerous gastrointestinal side effects have been reported with oral iron treatment as it is absorbed through the gastrointestinal system. A systematic review and meta-analysis study of 6.831 patients compared the efficacy of ferrous sulphate treatment with the efficacies of placebo and intravenous iron treatment and reported that oral iron treatment was associated with higher side effects than placebo and intravenous iron treatment $t^{6}$. In the present study, no significant difference was determined between the treatment groups in terms of mild allergic reactions. A meta-analysis reported that intravenous iron treatment 


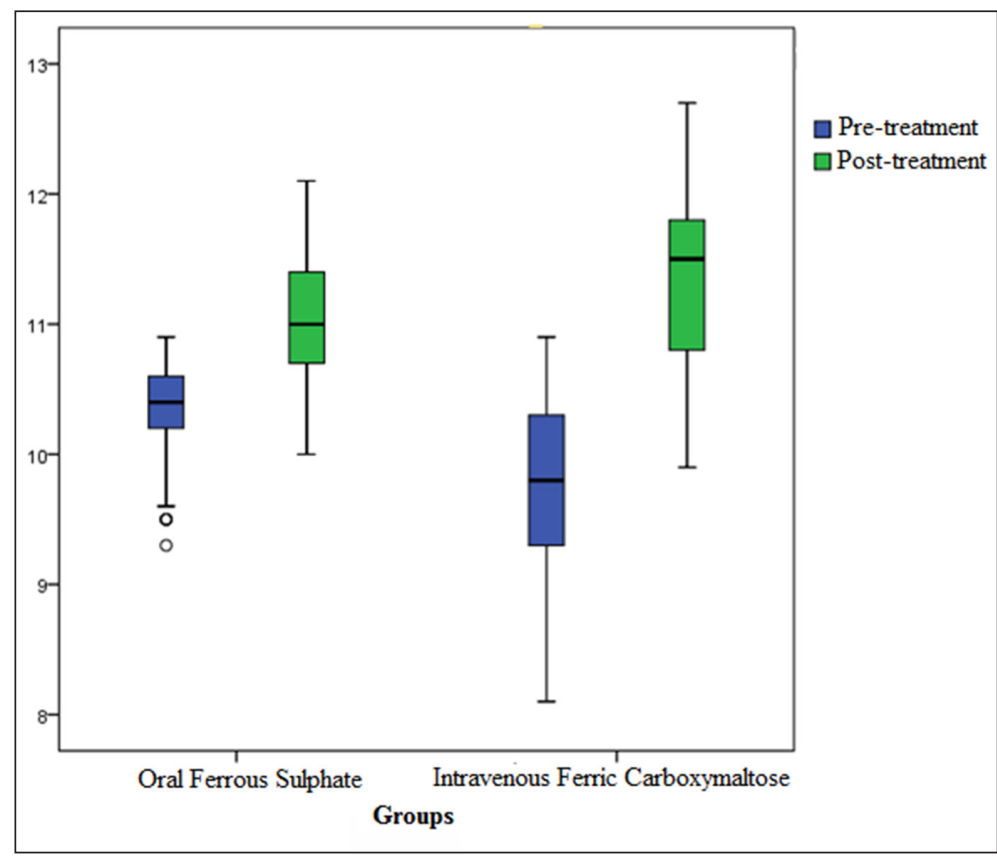

Figure 1. Distribution of hemoglobin concentration in the treatment groups.

was associated with lower transfusion and accordingly with lower transfusion-related side effects ${ }^{12}$. Likewise, a study of 252 patients reported lower side effects with intravenous iron treatment as compared with oral iron treatment ${ }^{15}$. Although some studies have demonstrated hypophosphatemia with ferric carboxymaltose treatment, no case with permanent damage has been reported $^{16,17}$.

The present study has some limitations. In addition to its retrospective nature, the main limitation is not evaluating the gastrointestinal side effects of the patients. Another limitation is not investigating the symptoms such as palpitation, weakness, poor concentration, and psychosomatic alterations, which would have been affected after the treatment with oral or intravenous iron preparations.

The present study revealed that ferric carboxymaltose treatment could be effectively used in the patients who were intolerant to oral iron preparations and in whom hemoglobin concentration was intended to be elevated rapidly. We are in the opinion that a single dose of ferric carboxymaltose treatment provides patients with ease of use and reduces additional treatment costs as compared with other intravenous iron preparations. The results of the present study need to be evaluated in further studies with larger patient groups.

\section{Conflict of Interest}

The authors report no conflicts of interest and no grant support. The authors alone are responsible for the content and writing of the paper. Also, no financial support was received.

\section{References}

1. Moore RA, Gaskell H, Rose P, Allan J. Meta-analysis of efficacy and safety of intravenous ferric carboxymaltose (Ferinject) from clinical trial reports and published trial data. BMC Blood Disord 2011;11:4.

2. Rognoni C, Venturini S, Meregaglia M, Marmifero M, Tarricone R. Efficacy and safety of ferric carboxymaltose and other formulations in iron-deficient patients: a systematic review and network meta-analysis of randomised controlled trials. Clin Drug Investig 2016;36:177-94.

3. World Health Organization. Haemoglobin concentrations for the diagnosis of anaemia and assessment of severity. Geneva, Switzerland, 2011. http=//www.who.int/vmnis/indicators/ haemoglobin.pdf [Accessed: 28/02/2019].

4. Shander A, Goodnough LT, Javidroozi M, Aurbach M, Carson J, Ershler WB, et al. Iron deficiency anemia-bridging the knowledge and practice gap. Transfus Med Rev 2014;28:156-66.

5. Auerbach M, Deloughery T. Single-dose intravenous iron for iron deficiency: a new paradigm. Hematology Am Soc Hematol Educ Program 2016;2016:57-66. 
6. Tolkien Z, Stecher L, Mander AP, Pereira DI, Powell JJ. Ferrous sulfate supplementation causes significant gastrointestinal sideeffects in adults: a systematic review and meta-analysis. PloS One 2015;10: e0117383.

7. Keating GM. Ferric carboxymaltose: a review of its use in iron deficiency. Drugs 2015;75:101-127.

8. Christoph P, Schuller C, Studer H, Irion O, De Tejada BM, Surbek D. Intravenous iron treatment in pregnancy: comparison of high-dose ferric carboxymaltose vs. iron sucrose. J Perinat Med 2012;40(5):469-74.

9. Seid MH, Derman RJ, Baker JB, Banach W, Goldberg C, Rogers R. Ferric carboxymaltose injection in the treatment of postpartum iron deficiency anemia: a randomized controlled clinical trial. Am J Obstet Gynecol 2008;199(4):435. e1-7.

10. Barut A, Harma M. Intravenous iron treatment for iron deficiency anaemia in pregnancy. J Turk Ger Gynecol Assoc 2009;10:109-115.

11. Rohrig G, Steinmetz T, Stein J, Geisel T, Virgin G, Schaefer $\mathrm{R}$, et al. Efficacy and tolerability of ferric carboxymaltose in geriatric patients with anemia. Data from three noninterventional studies. MMW Fortschr Med 2014 Jul 24;156 Suppl 2:48-53.
12. Litton E, Xiao J, Ho KM. Safety and efficacy of intravenous iron therapy in reducing requirement for allogeneic blood transfusion: systematic review and meta-analysis of randomised clinical trials. BMJ 2013 Aug 15;347: f4822.

13. Gürbüz DÇ, Ulaş T, Paksoy F, Akgün ÖK, Tursun İ, Çakır A, et al. The effect of intravenous iron therapy on total antioxidant capacity in patients with iron deficiency anemia. J Clin Exp Invest 2011;2:287-91.

14. Altinbaş M, Imamoğlu I, Albayrak M, Ersoy U, Hacibekiroğlu I, Çolak D. Evaluation of intravenous iron therapy efficiency in patients with iron deficiency anemia Ortadogu Medical Journal 2015, 7(2):79-82.

15. Breymann C, Milman N, Mezzacasa A, Bernard R, Dudenhausen J. Ferric carboxymaltose vs. oral iron in the treatment of pregnant women with iron deficiency anemia: an international, open-label, randomized controlled trial (FER-ASAP). J Perinat Med 2017;45(4):443-453.

16. Smyth B, Ong S. Severe hypocalcaemia and hypophosphataemia following intravenous iron and denosumab: a novel drug interaction. Intern Med J 2016;46(3):360-3.

17. Blazevic A, Hunze J, Boots JM. Severe hypophosphataemia after intravenous iron administration. Neth J Med 2014;72(1):49-53. 